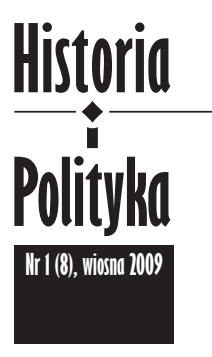

\section{Agnieszka Graboń, Problematyka żydowska na łamach prasy akademickiej w okresie międzywojennym, Kraków 2008, ss. 445}

$p$ olska historiografia w ciągu ostatnich kilkunastu lat poczyniła znaczące postępy w dziedzinie analizy zagadnienia mniejszości żydowskiej, zamieszkującej terytorium Drugiej Rzeczypospolitej. Wśród licznych prac, poruszających tę problematykę wspomnieć można chociażby o takich tytułach jak: „Stosunki polsko żydowskie w Wilnie i na Wileńszczyźnie 1919-1939" autorstwa Jarosława Wołkonowskiego, „Stosunek Narodowej Demokracji do kwestii żydowskiej w latach 1914-1919" Bogusława Sobczaka, „Mniejszość żydowska w parlamencie II Rzeczypospolitej:(1922-1939)" Janusza Fałowskiego, „Kwestia żydowska

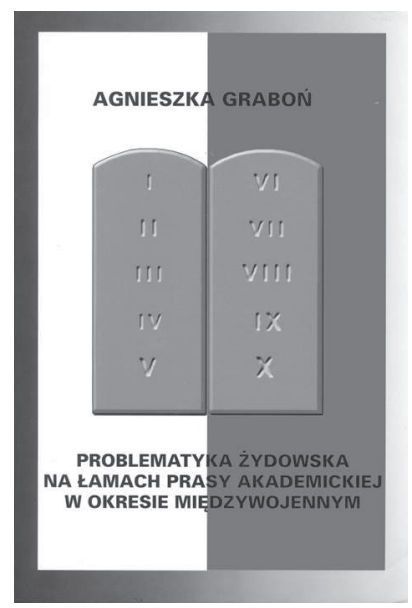
w publicystyce „Myśli Narodowej” w latach 1921-1926" Przemysława Jastrzębskiego, „Kościół katolicki wobec Żydów w Polsce międzywojennej" Damiana Pałki czy też "Numerus clausus, getto ławkowe, numerus nullus, „paragraf aryjski”: antysemityzm na Uniwersytecie Warszawskim 1931-1939" Moniki Natkowskiej. W ten nurt szeroko zakrojonych badań wpisuje się również praca powstała w roku 2008 w Zakładzie Historii Kultury i Oświaty Uniwersytetu Jagiellońskiego, której autorką jest Agnieszka Graboń. „Problematyka żydowska na łamach prasy akademickiej w okresie międzywojennym" - taki tytuł nosi przywoływana monografia jest tym samym kolejną próbą naświetlenia tego niezwykle ważnego aspektu dziejów Polski międzywojennej. Tym razem głównym punktem odniesienia jest stosunek młodzieży studenckiej różnych odcieni politycznych do kwestii żydowskiej, artykułowany na łamach ówczesnych periodyków akademickich.

Struktura pracy podzielona została na osiem rozdziałów, w których można wyróżnić trzy odrębne obszary. Trzy pierwsze rozdziały mają charakter wprowadzenia i skupiają się kolejno wokół następujących zagadnień: I - Ogólna charakterystyka społeczności żydowskiej, zamieszkującej obszar II RP. Uwzględnione tutaj zostały takie problemy jak: struktura demograficzna, społeczna, gospodarcza i zawodowa Żydów polskich, główne kierunki polityczne panujące $\mathrm{w}$ tym środowisku, a także stosunek polskich sił politycznych do tejże mniejszości; II - Krótka analiza sytuacji polskiego szkolnictwa wyższego w latach dwudziestych i trzydziestych, 
obejmująca zagadnienie aktywności społeczno-politycznej młodzieży akademickiej, ze szczególnym uwypukleniem roli prasy studenckiej, jako czynnika kreującego określone postawy i zachowania. III - Stereotyp ludności żydowskiej, utrwalony w znacznych odłamach społeczeństwa polskiego, głównie pod wpływem propagandy szeroko pojętego obozu narodowego. Druga część pracy, w której zawierają się rozdziały od IV do VI skupia się z kolei wokół kwestii szczególnie istotnych z punktu widzenia środowiska akademickiego, obejmujących dążenia do zaprowadzenia na polskich uczelniach wyższych zasad numerus clausus, numerus nullus, getta ławkowego oraz tzw. „paragrafu aryjskiego” oraz ich artykułowanie w najważniejszych tytułach prasowych redagowanych przez główne ideowo-polityczne ugrupowania studenckie. Część trzecia, obejmująca dwa ostatnie rozdziały, skupia się na przedstawieniu stosunku samych Żydów do projektowanych rozwiązań, prezentowanych na łamach polskiej prasy akademickiej.

Podstawowym atutem prezentowanej monografii jest bardzo wnikliwie i pieczołowicie przeprowadzona kwerenda źródłowa. Znajdziemy w niej oprócz całego szeregu licznych opracowań ogólnych, wspomnień, źródeł drukowanych także niezwykle bogatą bibliografię prasową. Autorka przytacza tu setki, jeśli nie tysiące artykułów, zamieszczanych na łamach prasy narodowej, chadeckiej, sanacyjnej, socjalistycznej, komunistycznej i żydowskiej. Faktem wartym podkreślenia jest także to, że w pracy oprócz odniesień do powszechnie znanych periodyków akademickich znajdujemy również przypisy do tytułów wychodzących sporadycznie lub tylko okazjonalnie. Są to między innymi „Akademicka Jednodniówka Wyborcza”, „Alma Mater Vilnensis”, „Biuletyn Arkoński”, „Blokadol”, „Korporant”, „Vox Universitatis” i wiele, wiele innych. Podnosi to również wartość merytoryczną samej pracy.

Mimo tych dość oczywistych pozytywów nie sposób jednak nie poczynić kilku uwag krytycznych. Dotyczą one przede wszystkim konstrukcji opracowania, jak również jego zawartości. Dziwi przede wszystkim przyjęcie swoistego „endeckiego klucza" głównych zagadnień, które zostają tym samym potraktowane jako punkt wyjścia dla dalszej analizy. Z jednej strony można zrozumieć ten zabieg autorki, która zdaje się sugerować dominację koncepcji narodowych w ówczesnym dyskursie politycznym. Z drugiej jednak przyjęcie takiego rozwiązania wprowadza do pracy pewien chaos, którego dałoby się uniknąć przyjmując schemat strukturalny, w którym w kolejnych rozdziałach opisane zostałyby poglądy najważniejszych młodzieżowych grup politycznych na kwestię żydowską. Struktura zastosowana przez autorkę ma jeszcze tę dodatkową wadę, iż siłą rzeczy stanowisko endeckich organizacji studenckich zostało tutaj szczególnie mocno wyeksponowane kosztem pozostałych. Co więcej w samym układzie pracy daje się jeszcze zauważyć pewną niekonsekwencję, której przejawem są dwa ostatnie rozdziały, w których przeprowadzono analizę stosunku prasy żydowskiej do projektów getta ławkowego, numerus clausus, czy paragrafu aryjskiego, które były szczegółowo rozpatrywane we wcześniejszych fragmentach powyższego opracowania. W ten sposób czytelnik w końcowej partii pracy musi po raz kolejny przebrnąć przez problematykę, z którą zapoznawał się już wcześniej. 
Różnica polega jedynie na tym, iż może na nią spojrzeć niejako „oczyma” mniejszości żydowskiej.

Druga istotną kwestię stanowi treść pracy. Niezwykle szczegółowa bibliografia zwłaszcza w odniesieniu do artykułów prasowych pozwala na wszechstronne spojrzenie na omawianą tutaj problematykę. Niestety pewnym mankamentem są tutaj nieliczne powtórzenia. I tak np. podrozdział trzeci rozdziału V, zatytułowany „Walka między odłamami młodzieży o «rząd dusz» ze sprawą żydowską w tle" jest de facto skondensowanym streszczeniem pozostałych części, omawiających relacje poszczególnych odłamów młodzieży w stosunku do ludności żydowskiej. Podobne powtórzenie pojawia się jeszcze $\mathrm{w}$ podrozdziale drugim rozdziału VI, w którym ponownie pojawia się kwestia getta ławkowego.

Kwestia trzecia to obiektywizm pracy. Mimo, iż autorce udało się wskazać na czynniki wpływające na złożoność stosunków polsko-żydowskich, to nie ustrzegła się jednak pewnych generalizacji. Znalazło to bardzo jaskrawy wyraz w wykreowanym obrazie szeroko pojmowanego środowiska endeckiego. Z rozważań Agnieszki Graboń wyłania się bowiem wizerunek narodowca-pałkarza, zawsze gotowego do awantur i bójek. Mniejszość żydowska jawi się tu natomiast jako bezbronna ofiara. Nikt nie neguje faktu, iż przemoc była jednym z narzędzi walki politycznej, wykorzystywanym przez ruch narodowy. Należy jednak pamiętać, iż okres dwudziestolecia międzywojennego, w którym jak zwykło się mawiać „polityka wyszła na ulicę" był czasem, w którym uliczne starcia bojówek partyjnych były zjawiskiem powszechnym. Nie stroniły od nich ani ugrupowania prawicy, ani lewicy. Rów- nież i strona żydowska posiadała własne grupy bojowe, które wdawały się w burdy $\mathrm{z}$ młodzieżą polską (przykładem może być chociażby syjonistyczna organizacja Betar). Szczególnie interesująca może być w tym względzie opinia historyka, tworzącego w czasach PRL-u (trudno więc posądzać go o jakieś endeckie koneksje) Jana Borkowskiego: „Jest rzeczą niewątpliwą, że nacjonaliści polscy pragnęli zaognienia stosunków polsko-żydowskich, ale i nacjonaliści żydowscy nie dążyli do ich załagodzenia. I oni zachowywali się agresywnie. W starciach między studentami w 1931 r. zginął nie Żyd, lecz Polak Stanisław Wacławski; tak było i w 1932 r., kiedy we Lwowie zabity został polski student Jan Grotkowski. W 1935 r. jakiś chłop zginął z rąk Żyda w Marcinkańcach, także w Grodnie zginął Polak. W Mińsku w czerwcu 1936 r. Żyd zabił wachmistrza Jana Bujaka, co rozpętało napady na sklepy żydowskie. W maju 1937 r. syn rzeźnika żydowskiego zabił policjanta, który dokonywał konfiskaty mięsa $\mathrm{z}$ uboju nielegalnego, co znów wywołało zaburzenia antyżydowskie. Należałoby zliczyć, ilu ludzi zginęło w tych zajściach; jest wielce prawdopodobne, że więcej ofiar ponieśli Polacy niż Żydzi."1. Pogląd ten podziela także inny historyk Marek Chodakiewicz, który w swojej pracy „Ciemnogród? 0 prawicy i lewicy” pisze: „Żydzi nie przyglądali się biernie atakom na siebie. Istniały żydowskie grupy samoobrony. W burdach i zamieszkach padały ofiary po obu stronach. Co więcej żydowska mniejszość była czasami stroną atakującą"2. Należy

1 J. Borkowski, O społeczeństwie Drugiej Rzeczypospolitej, Przegląd Humanistyczny 1974, nr 7, s. 133.

2 M. J. Chodakiewicz, Ciemnogród? O prawicy i lewicy, Warszawa 1996, s. 181. 
jednak pamiętać, iż nie wszyscy członkowie i zwolennicy endecji jednoznacznie aprobowali siłowe rozwiązywanie konfliktu polsko-żydowskiego. Zdarzały się bowiem przypadki, w których aktywiści endeccy potępiali antysemickie ekscesy. Do takich należał chociażby jeden z głównych liderów lwowskiej Młodzieży Wszechpolskiej Witold Nowosad, który mimo iż nie unikał antyżydowskiej retoryki to jednak negował przemoc, jako metodę politycznej rywalizacji ${ }^{3}$, czemu dawał wyraz w swoich publicznych wystąpieniach.

Kolejna kwestia, z którą nie sposób zgodzić się z autorką książki to sugestie, według których ruch narodowy miałby sympatyzować z niemieckim nazizmem. Na dowód tychże sympatii przytoczono w pracy fragmenty wypowiedzi, które świadczyć mogą o entuzjazmie w odniesieniu do hitleryzmu. Jest oczywiście prawdą, że antyżydowską polityką III Rzeszy realizowaną w latach 30. żywo interesowano się w kołach endeckich. Jednakże wskazywanie na rasistowskie zapatrywania narodowych socjalistów niemieckich, jako na źródło inspiracji ideowych polskich narodowców stanowi zbyt duże uproszczenie. Zarówno prasa narodowa, jak i poszczególni działacze jednoznacznie potępiali rasowe teorie, lansowane przez nazistów ${ }^{4}$. Jednym z przykładów może być tutaj fragment artykułu zamieszczony przez znanego

3 J. Wawrzków, Lwowska Młodzież Wszechpolska, Glaukopis, nr 5-6 2006, s. 79.

${ }_{4}$ Zob. K. Kawalec, Narodowa Demokracja wobec faszyzmu 1922-1939: ze studiów nad dziejami myśli politycznej obozu narodowego, Warszawa 1989; M. Marszał, Włoski faszyzm i niemiecki narodowy socjalizm $w$ poglądach ideologów Narodowej Demokracji 1926-1939, Kolonia Limited 2001; A. S. Kotowski, Narodowa Demokracja wobec nazizmu i trzeciej rzeszy, Toruń 2007. działacza narodowego Antoniego Malatyńskiego na łamach „Warszawskiego Dziennika Narodowego”: „Doktryna hitleryzmu jest nam obca. Nikt jako żywo, nie słyszał z ust narodowca aprobaty hitlerowskiej teorii rasizmu - tej teorii zbudowanej na czysto materialistycznych przesłankach. Nikt również nie słyszał aprobaty neopoganizmu. Nasz światopogląd, a światopogląd hitlerowski to są dwie rzeczy całkiem różne, oparte na innych założeniach i przesłankach rozumowych, a nawet na innych uczuciach, dążeniach i instynktach" ${ }^{\text {5. W }}$ ciekawy sposób postawa narodowców została scharakteryzowana przez Lucjana Blita, działacz żydowskiej partii Bund: „Narodowcy polscy [...] odczuwali wielkie psychologiczne i inne trudności w zaakceptowaniu idei faszyzmu i narodowego socjalizmu [...]. Nie byli rewolucjonistami jak naziści w Niemczech czy faszyści we Włoszech; byli staroświeckimi reakcjonistami. Aktywnie organizowali bojkot ekonomiczny, ale nie zachęcali do fizycznych pogromów"6.

Dokonując oceny rzeczywistej wartości pracy Agnieszki Graboń docenić należy przede wszystkim niezwykle dokładnie przeprowadzoną kwerendę oraz chęć ukazania różnorodności stanowisk poszczególnych grup młodzieży polskiej w odniesieniu do problemu żydowskiego. Elementy te z całą pewnością stanowią ważny punkt pracy, której zamiarem było poruszenie tak istotnego zagadnienia jak relacje polsko-żydowskie w II Rzeczypospolitej. Nie udało się

${ }^{5}$ A. Malatyński, Hitler, Żydzi i komunizm, Warszawski Dziennik Narodowy, 1 VIII 1935 s. 2.

${ }^{6}$ M. J. Chodakiewicz, Żydzi i Polacy. Współistnienie - zagłada - komunizm, Warszawa 2000, s. 42 . 
jednak autorce uniknąć pewnych utartych schematów, jakie dość powszechnie panują w historiograficznych ocenach omawianej materii. Mimo to opracowanie niniejsze należy uznać, jako ważny krok na drodze dalszych pogłębionych badań nad dziejami wzajemnych stosunków obu narodów.

Jacek Misztal (Toruń) 